\title{
Platelet adhesiveness, coagulation, and fibrinolytic activity in obesity
}

\author{
C. P. WARLOW, A. McNeIll, D. OGSTON, AND A. S. DOUGLAS
}

From the Department of Medicine, University of Aberdeen

SYNOPSIS In a study of 41 fasting subjects it was confirmed that fibrinolytic activity was reduced in obese persons: an increase in fibrinogen was also associated with obesity. There was no correlation between obesity and the platelet count, platelet adhesiveness to glass, the level of serum fibrin degradation products, or the whole blood clotting time in plastic tubes.

Obesity has been incriminated in the pathogenesis of occlusive coronary artery disease (Dawber, Moore, and Mann; 1957; Stamler, Lindberg, Berkson, Shaffer, Miller, Poindexter, Colwell, and Hall, 1960) and venous thromboembolic disease (Vessey and Doll, 1969; Kakkar, Howe, Nicolaides, Renney, and Clarke, 1970). In this study a number of haemostatic parameters, including platelet adhesiveness, fibrinolytic activity, and the clotting time in plastic tubes, have been measured in subjects of varying obesity.

\section{Methods and Subjects}

\section{PLASMINOGEN ACTIVATOR}

This was assayed by performing euglobulin clot lysis times by the method of Nilsson and Olow (1962). The results are expressed by plotting the times logarithmically against units of fibrinolytic activity (Sherry, Lindemeyer, Fletcher, and Alkjaersig, 1959), 10 units being arbitrarily equated with a lysis time of 50 minutes. Times of over 500 minutes were assigned a value of 1 unit for the purpose of calculation.

Plasminogen activator was also measured by placing $30 \mu \mathrm{l}$ of resuspended euglobulin precipitation on fibrin plates prepared from $0.2 \%$ human fibrinogen (grade L, AB Kabi, Stockholm). After incubation at $35^{\circ} \mathrm{C}$ for 24 hours the area of lysis was estimated from the product of two diameters at right angles to each other.

A partially purified preparation of urokinase (Leo Pharmaceutical Products, Ballerup, Denmark) was used as a reference standard. The areas of lysis produced by the urokinase standard dilutions were Received for publication 11 February 1972. plotted on a log-log scale and the fibrinolytic activity of the euglobulin precipitate obtained by extrapolation and expressed as Ploug units of urokinase (Ploug and Kjeldgaard, 1957).

PLASMA FIBRINOGEN

Plasma fibrinogen was measured by a modification (Ogston and Ogston, 1966) of the method of Ratnoff and Menzie (1951).

DEGRADATION PRODUCTS

Serum fibrin degradation products were assayed by the method of Merskey, Kleiner, and Johnson (1966) with minor modifications outlined by Bonnar, Davidson, Pidgeon, McNicol, and Douglas (1969).

Platelet ADHesiveness

This was measured by a modification of the method of Payling Wright (1941). Blood was withdrawn with a polypropylene syringe and mixed with 1 vol of $3.8 \%$ sodium citrate in a polypropylene tube. After standing for 60 minutes rotation at $3 \frac{1}{2} \mathrm{rpm}$ in a glass bulb was started. A platelet count was made before and after rotation for 20 minutes. Platelet $O$ adhesiveness was taken as the difference in the $N$ platelet count expressed as a percentage of the pre-rotation count.

\section{SUBJECTS}

Forty-one healthy volunteers and patients attending an obesity clinic comprised the subjects of this study. There were eight men and 33 women. Apart from obesity all were in good health. None had fluctuated markedly in weight in the weeks before testing. All subjects had fasted for 12 hours and none were taking any drugs known to influence haemostatic 
parameters. None had undertaken more than minimal exercise on the morning of testing and all rested for 30 minutes before venepuncture was performed. The age range was from 16 to 64 years.

\section{ASSESSMENT OF OBESITY}

The ratio of the observed to standard weight was calculated from the weight-for-height standard of Kemsley, Billewicz, and Thomson (1962). No age adjustments were made.

\section{Results}

FIBRINOLYTIC ACTIVITY

Circulating plasminogen activator levels were assayed by two techniques. The measurement of activator by the euglobulin clot lysis time method may be influenced by variations in the concentration of other components of the euglobulin precipitate, in particular, fibrinogen and plasminogen. The fibrin plate technique avoids this possible source of error by the use of an exogenous substrate. The Table shows that the mean plasminogen activator levels, assayed by both techniques, were significantly reduced in the obese persons, and it is concluded that the increased fibrinogen concentration is not the explanation for the decreased activator levels. It may be noted that, in spite of the reduced activator levels in the obese groups, the level of serum fibrin degradation products did not differ significantly between the groups.

\begin{tabular}{|c|c|c|c|}
\hline & \multicolumn{3}{|c|}{ Observed/Standard Weight Ratio } \\
\hline & $\begin{array}{l}91-120 \\
(n=12)\end{array}$ & $\begin{array}{l}121-150 \\
(n=17)\end{array}$ & $\begin{array}{l}151-190 \\
(n=12)\end{array}$ \\
\hline $\begin{array}{l}\text { Mean age (yr) } \\
\text { Plasminogen activator }\end{array}$ & $33 \cdot 8$ & $38 \cdot 8$ & $38 \cdot 2$ \\
\hline $\begin{array}{l}\text { Euglobulin lysis } \\
\text { time (units) } \\
\text { Fibrin plate (units) } \\
\text { Fibrinogen (mg/100 ml) } \\
\text { Fibrin degradation products }\end{array}$ & $\begin{array}{l}4 \cdot 3 \pm 1 \cdot 6 \\
1 \cdot 08 \pm 0 \cdot 53 \\
326 \pm 39 \\
\end{array}$ & $\begin{array}{c}2 \cdot 7 \pm 1 \cdot 5^{2} \\
0 \cdot 66 \pm 0 \cdot 42^{1} \\
356 \pm 61\end{array}$ & $\begin{array}{l}1 \cdot 9 \pm 1 \cdot 1^{3} \\
0 \cdot 27 \pm 0 \cdot 14^{3} \\
363 \pm 39^{1}\end{array}$ \\
\hline $\begin{array}{l}(\mu \mathrm{g} / \mathrm{ml}) \\
\text { Platelet adhesiveness }(\%) \\
\text { Platelet count }\end{array}$ & $\begin{array}{r}2 \cdot 4 \pm 3 \cdot 0 \\
31 \cdot 9 \pm 8 \cdot 5\end{array}$ & $\begin{array}{r}2 \cdot 9 \pm 2 \cdot 4 \\
38 \cdot 2 \pm 8 \cdot 4\end{array}$ & $\begin{array}{c}1.4 \pm 1.9 \\
37.9 \pm 10.7\end{array}$ \\
\hline$\left(\times 1000 \mathrm{~mm}^{3}\right)$ & $231 \pm 44$ & $223 \pm 50$ & $209 \pm 34$ \\
\hline
\end{tabular}

Table Mean changes with $S D$ in fibrinolytic activity, fibrinogen, fibrin degradation products, platelet adhesiveness, and platelet count in obese and non-obese groups

Significance of differences from means of $\mathrm{O} / \mathrm{S}$ ratio $91-120$ group: ${ }^{1} P<0.05,{ }^{2} P<0.01,{ }^{3} P<0.001$.

\section{PLATELET ADHESIVENESS}

The percentage of platelets lost after rotation of the samples of citrated blood was higher in the obese subjects, but the differences did not reach statistical significance. In addition, the correlation between observed/standard weight ratio and platelet adhesiveness was not significant $(r=+0.061: P>0.1)$.

The mean platelet count did not differ significantly between the obese and non-obese groups.

\section{CLOTTING TIME}

The clotting time in plastic tubes was carried out on blood obtained from 15 women of varying observed/ standard weight ratio: the correlation between the clotting times and the weight ratio was not significant $(r=+0.32 ; P>0.1)$.

\section{Discussion}

The association of decreased plasma fibrinolytic activity with obesity has been noted by several investigators (Goldrick, 1961; Shaw and McNaughton, 1963; Ogston and McAndrew, 1964; Grace and Goldrick, 1968). The reduction in plasminogen activator levels, as assessed on fibrin plates, indicates that low fibrinolytic activity in obese subjects is not due to substrate differences in the euglobulin precipitate. The finding of increased fibrinogen levels in obese persons confirms previous observations (Ogston and McAndrew, 1964; Bennett, Ogston, McAndrew, and Ogston, 1966; Grace and Goldrick, 1968).

The mechanism of the low plasma fibrinolytic activity in obese persons has not been elucidated. It is not due to alteration in the level of inhibitors of the fibrinolytic enzyme system (Bennett et al, 1966), and the release of plasminogen activator response to venous stasis has been found to be normal (Grace, 1968). In spite of the low fibrinolytic activity the obese subjects had a normal level of fibrin degradation products, suggesting a normal mechanism for the removal of fibrin deposits. Relevant to this finding are the observations of Grace and Goldrick (1969) that tissue activation levels are normal in obese persons.

The effect of obesity on platelet adhesiveness has not, to our knowledge, been studied previously. Although the rotating bulb technique used in this study has a number of inherent disadvantages, it has demonstrated increased platelet adhesiveness in situations associated with an increased incidence of venous or arterial thrombosis. Examples include the postoperative period (Wright, 1942; Bennett, 1967; Ham and Slack, 1967; Negus, Pinto, and Brown, 1969), ischaemic heart disease (McDonald, Bray, and Edgill, 1958), and homocystinuria (McDonald, Bray, Field, Love, and Davies, 1964). We have, however, been unable to demonstrate an alteration in platelet adhesiveness in obese persons. In addition, in agreement with Grace, Sinnett, and Whyte (1970) 
we have found no relationship between obesity and overall measurements of blood coagulability.

Measurements of platelet adhesiveness to glass and the whole blood clotting time in plastic tubes lack sensitivity and have limitations as indicators of a prethrombotic state. In consequence, definite conclusions on the role of platelet adhesiveness and coagulation in the mediation of the relationship between obesity and thrombosis cannot be made. Our results would suggest, however, that alteration in fibrinolytic activity may be a more important factor in this relationship.

These studies were made possible by the technical assistance of Mrs Helen Lee and Mrs Naomi Hoogstadt. We are indebted to those members of the Aberdeen Silhouette Slimming Club who volunteered to take part in this study.

\section{References}

Bennett, N. B., Ogston, C. M., McAndrew, G. M., and Ogston, D. (1966). Studies on the fibrinolytic enzyme system in obesity. J. clin. Path., 19, 241-243.

Bennett, P. N. (1967). Postoperative changes in platelet adhesiveness. J. clin. Path., 20, 708-709.

Bonnar, J., Davidson, J. F., Pidgeon, C. F., McNicol, G. P., and Douglas, A. S. (1969). Fibrin degradation products in normal and abnormal pregnancy and parturition. Brit. med. J., 3, 137-140.

Dawber, T. R., Moore, F. E., and Mann, G. V. (1957). Coronary heart disease in the Framingham Study. Amer. J. publ. Hlth, 47, Suppl., 4-24.

Goldrick, R. B. (1951). Fibrinolysis, blood clotting, serum lipids and body build in natives of New Guinea and Australians. Aust. Ann. Med., 10, 20-28.

Grace, C. S. (1958). The fibrinolytic enzyme system in obesity: the effects of venous occlusion and in vitro activation by surface contact. Clin. Sci., 34, 497-504.

Grace, C. S., and Goldrick, R. B. (1968). Fibrinolysis and body build Inter-relationships between blood fibrinolysis, body composition and parameters of lipid and carbohydrate metabolism. J. Atheroscler. Res., 8, 705-719.

Grace, C. S., and Goldrick, R. B. (1969). Tissue fibrinolytic activity in obesity. Aust. J. exp. Biol. med., Sci., 47, 397-400.
Grace, C. S., Sinnett, P. F., and Whyte, H. M. (1970). Blood fibrinolysis and coagulation in New Guineans and Australians. Aust. Ann. Med., 19, 328-333.

Ham, J. M., and Slack, W. W. (1967). Platelet adhesiveness after operation. Brit. J. Surg., 54, 385-389.

Kakkar, V. V., Howe, C. T., Nicolaides, A. N., Renney, J. T. G., and Clarke, M. B. (1970). Deep vein thrombosis of the leg. Is there a "high risk" group? Amer. J. Surg., 120, 527-530.

Kemsley, W. F. F., Billewicz, W. Z., and Thomson, A. M. (1962). $\frac{\bar{\sigma}}{\supset}$ A new weight-for-height standard based on British anthropo- $\mathbb{D}$ metric data. Brit. J. prev. soc. Med., 16, 189-195.

McDonald, L., Bray, C., Field, C., Love, F., and Davies, B. (1964). ڤి Homocystinuria, thrombosis and the blood platelets. Lancet, 1, 745-746.

McDonald, L., and Edgill, M. (1957). Coagulability of the blood in ischaemic heart-disease. Lancet, 2, 457-460.

Merskey, C., Kleiner, G. J., and Johnson, A. J. (1966). Quantitative estimation of split products of fibrinogen in human serum, $\frac{\Omega}{O}$
relation to diagnosis and treatment. Blood, 28, 1-18.

Negus, D., Pinto, D. J., and Brown, N. (1969). Platelet adhesiveness iv in postoperative deep-vein thrombosis. Lancet, 1, 220-224. G

Nilsson, I. M., and Olow, B. (1962). Fibrinolysis induced by strepto- o' kinase in man. Acta chir. scand., 123, 247-266.

Ogston, C. M., and Ogston, D. (1966). Plasma flbrinogen and $\infty$ plasminogin levels in health and in ischaemic heart disease. J. clin. Path., 19, 352-356.

Ogston, D., and McAndrew, G. M. (1964). Fibrinolysis in obesity. Lancet, 2, 1205-1207.

Ploug, J., and Kjeldgaard, N. O. (1957). Urokinase, an activator of $\subseteq$ plasminogen from human urine: isolation and properties. $\frac{\vec{D}}{(\mathrm{D}}$ Biochim. biophys. Acta (Amst.), 24, 278-282.

Ratnoff, O. D., and Menzie, C. (1951). A new method for the deter- $\vec{\bullet}$ mination of fibrinogen in small samples of plasma. J. Lab. clin. N
Med., 37, 316-320.

Shaw, D. A. and MacNaughton, D. (1963). Relationship between $\square$ blood fibrinolytic activity and body fatness. Lancet, 1, 352-354.

Sherry, S., Lindemeyer, R. I., Fletcher, A. P., and Alkjaersig, N. (1959). Studies on enhanced fibrinolytic activity in man. J. clin. Invest., 38, 810-822.

Stamler, J., Lindberg, H. A., Berkson, D. M., Shaffer, A., Miller, W., อ Poindexter, A., Colwell, M., and Hall, Y. (1960). Prevalence $\mathbb{D}$ and incidence of coronary heart disease in strata of the labor force of a Chicago industrial corporation. J. chron. Dis., 11, $\overrightarrow{\bar{O}}$ 405-420.

Vessey, M. P., and Doll, R. (1969). Investigation of relation between use of oral contraceptives and thromboembolic disease: a further report. Brit. med. J., 2, 651-657.

Wright, H. P. (1941). The adhesiveness of blood platelets in normal subjects with varying concentrations of anticoagulants. J. Path. Bact., 53, 255-262.

Wright, H.P.(1942). Changes in the adhesiveness of platelets following parturition and surgical operation. J. Path. Bact., 54, 461-468.ב 